Immunobiology and Immunopharmacology Unit, Animal Reproduction Research Institute, Giza, Egypt.

\title{
THE USE OF LATEX AGGLUTINATION TEST AS A RAPID METHOD FOR DETECTION OF ANTIBODIES TO MYCOPLASMA BOVIS IN COMPARISON WITH ELISA
}

(With 2 Tables and 2 Charts)

By

\section{S.M. ABDEL HAFEZ; M.H. YASSIN* and A.M.GOMAA**}

* Dept. of Reproductive Disease, Animal Reproduction Research Institute, Giza, Egypt.

** Dept. of Udder and Neonates, Animal Reproduction Research Institute, Giza, Egypt. (Received at 8/3/2009)

\section{إستخدام إختبار تلزن اللاتكس كطريقة سريعة للكثف عن الأجسام المضادة

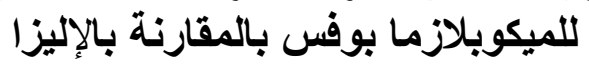
سلامة عبل الحافظ ، مجلى باسبين حسن ، علاء محمد جمعة

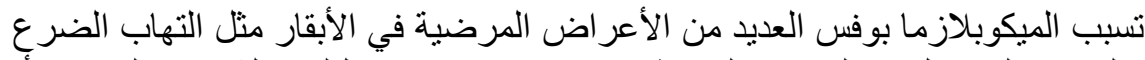

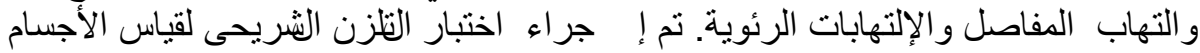

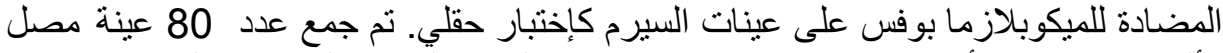

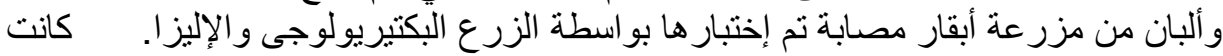

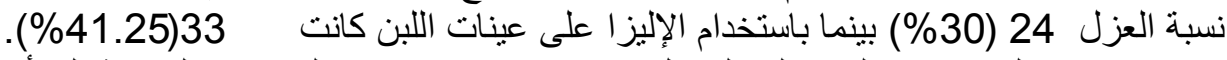

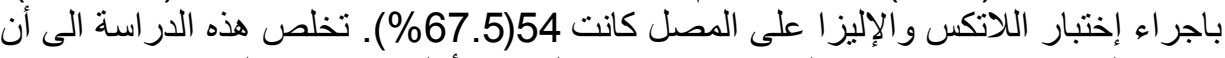

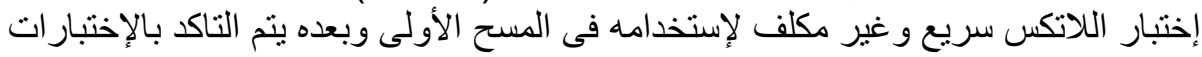

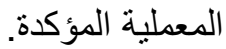

\section{SUMMARY}

Mycoplasma bovis (M. bovis) induces various clinical manifestations in cattle, such as mastitis, arthritis, and pneumonia. A latex agglutination test (LAT) has been developed to detect antibodies in bovine sera as a field test. A total of 80 milk and serum samples collected from a confirmed infected bovine farm were tested by conventional cultural method and indirect enzyme linked immunosorbant assay (ELISA). Milk samples cultivation revealed positive in only 24 (30\%) while ELISA 
detected $33(41.25 \%)$. LAT and ELISA on serum samples detected only $54(67.5 \%)$ of samples. LAT allows rapid and inexpensive test that could be useful in the field for primary herd screening prior to confirmatory laboratory diagnosis of $M$. bovis.

Key words: $M$. bovis, latex agglutination test, ELISA, cultivation.

\section{INTRODUCTION}

Mycoplasmas belong to the class Mollicutes which also contain ureaplasmas, acholeplasmas, spiroplasmas. They are characterized by small size (500-1100 kbp), lack of cell wall, and higher mutation rates than conventional bacteria and can rapidly develop resistance to antibiotics (Ayling et al., 2000 and Nicholas and Ayling, 2003).

Mycoplasma bovis (M. bovis) is an important and emerging cause of respiratory disease and arthritis in dairy cattle and veal calves, also has a variety of other disease manifestations. M. bovis is certainly capable of causing acute respiratory disease. In contrast, $M$. bovis is more accepted as a cause of chronic bronchopneumonia with caseous and perhaps coagulative necrosis (Kinde et al.,1993; Pfutzner and Sachse, 1996, Caswell and Archambault, 2007 and Wilson et al., 2007).

Mycoplasmal bovine mastitis is potentially a highly contagious disease that can cause severe economic problems in affected herds. The purchase of replacement heifers and cows are frequently the origin of mycoplasmal mastitis. Detection of mycoplasma infected cows by culture of milk is the only technique used for routine diagnosis at present. However, this process is rather laborious and time consuming where the final results are available only after several days (González and Wilson, 2003).

A number of modern tests have recently been described, including PCR (Bernadette and Robert, 2003) and ELISA, although these tests can offer advantages in term of sensitivity, specificity or reproducibility, they still require considerable investment in equipments and trained personnel and cannot be used for rapid diagnosis since they must be performed in the laboratory. As an aid to effective field control, a rapid and inexpensive test is needed for the accurate diagnosis (Martenz et al., 1990).

The aim of this work was to produce a new rapid and inexpensive field test, latex agglutination test (LAT) for primary herd screening prior to confirmatory laboratory diagnosis of $M$. bovis. 


\section{MATERIALS and METHODS}

\section{1- Samples:}

A total of 80 milk and blood samples were collected from lactating cattle farm for bacteriological isolation, ELISA and Latex agglutination test. Negative control samples were taken from 10 newly born calves $24-48$ hours of age and 10 serum and milk samples from non- infected cow's farm.

\section{2-Organisms:}

M. bovis reference strain was obtained from Prof. Dr. Ruhnke, Vet. Microbiol. Dept., Ontario Vet. College, Guelph Ontario, Canada.

\section{3- Bacterial isolation and identification of $M$. bovis:}

Isolation and identification of mycoplasma from milk samples was done according to Ruhnke and Rosendal, (1989).

\section{3- Preparation of Mycoplasma antigen:}

One $\mathrm{ml}$ of an active growing approximately $10^{7} \mathrm{CFU} / \mathrm{ml}$ estimated according to Rodwell and Whitcomb (1983) culture of $M$. bovis was first transferred into $9 \mathrm{ml}$ of broth (supplemented with horse serum, yeast extract DNA, pencillin G sodium and thallium acetate). After 72 hours incubation, the contents were aseptically poured into $90 \mathrm{ml}$ heart infusion broth and then after incubation period of 72 hours the content flasks (approx. 100ml) were transferred to the final propagation flask containing $900 \mathrm{ml}$ of broth. After another 72 hours of incubation, the mycoplasma cells were harvested by centrifugation at $18000 \mathrm{rpm}$ in cooling centrifuge for 1 hour. Sterility checks were routinely carried out with each passage of the growth to eliminate the possibility of bacterial contaminant. After two thorough washing in sterile PBS, cells were resuspended in $15 \mathrm{ml}$ of PBS/ $1000 \mathrm{ml}$ of the original volume (Ruhnke and Rosendal, 1989). This stock suspension was sonicated (Bandelin electronic UW2070 Sonicator) at $20 \mathrm{Kc} / \mathrm{min}$ for 10 successive times on ice and one minute interval (Krogsgaard, 1971).

\section{4- Enzyme Linked ImmunoSorbent Assay (ELISA):}

This test was carried out to estimate the M. bovis antibodies in serum and milk whey. In this test 80 milk samples and serum collected from lactating cows and the test done according to method of Hajkova and Jurmanova, (1986).

\section{5- Sensitization of Latex microspheres:}

The following procedure is slightly modified from Kende, (1969). A latex polystyrene microspheres particles of $0.81 \mu \mathrm{m}$ diameter (LB8; Sigma) were used in the covalent binding reaction. Prior to use, 
the beads were suspended in deionized water and vigorously vortexes to ensure even distribution to break up any large particles and obtain a 10\% suspension. An equal volume of latex particle and M. bovis sonicated antigens $\left(0.8 \mathrm{mg}\right.$ protein/ml) were incubated over night at $37{ }^{\circ} \mathrm{C}$. The mixture was end-to-end shacked and then centrifuged at $6,000 \mathrm{rpm}$ for $10 \mathrm{~min}$. The supernatant was removed and the pellet was washed and brought to a volume $10 \%$ in glycine sodium chloride buffer $(\mathrm{pH} 8.2$ with $1 \mathrm{~N} \mathrm{NaOH}$ ) containing 1:500 bovine serum albumin to keep the latex well suspended $(7.50 \mathrm{~g}$ of glycine, $5.85 \mathrm{~g}$ of sodium chloride and $0.1 \%$ sodium azide in 1 liter deionized water, and Evans blue $0.005 \mathrm{~g} \%$ ), kept at $4^{\circ} \mathrm{C}$.

\section{6-Latex agglutination tests:}

Agglutination test was performed on negative, field and positive ref. serum samples. Agglutination reactions were performed by adding a drop of latex solution into a drop of serum on a microscope glass slide and mixed by side to side movement of slide. The agglutination appears within 2-3 minutes in positive cases (Satynaran, et al., 1988).

\section{RESULTS}

\section{Bacteriological isolation:}

Results of M.bovis isolation from milk are illustrated in Table (1). Twenty four milk samples revealed positive culture (30\%) while $33(41.25 \%)$ of the milk samples revealed positive by ELISA titer to M. bovis.

\section{ELISA}

Also the ten control milk samples were negative by isolation and

Fifty four samples were positive $(67.5 \%)$ by LAT and ELISA in Table (2) the duration of latex was valid for 6 months. LAT and ELISA were applied on twenty control negative serum samples to exclude the false positive.

Table 1: Results of culture method and ELISA on milk samples:

\begin{tabular}{|l|c|c|c|c|}
\hline \multirow{2}{*}{ No. of samples } & \multicolumn{2}{|c|}{ Isolation } & \multicolumn{2}{c|}{ ELISA } \\
\cline { 2 - 5 } & positive & negative & Positive & negative \\
\hline 80 milk samples & $24(30 \%)$ & $56(70 \%)$ & $33(41.25 \%)$ & $47(58.75 \%)$ \\
\hline
\end{tabular}




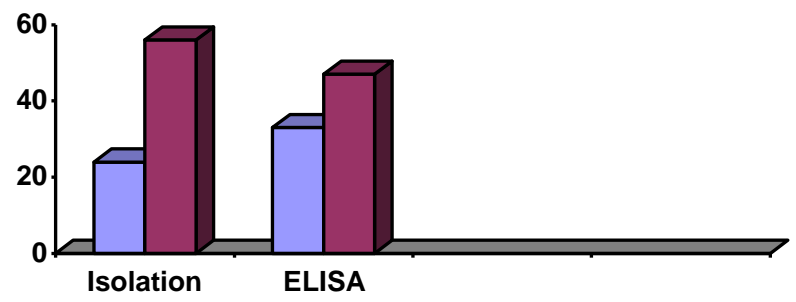

Chart 1: results of culture method and ELISA on milk samples

Table 2: Results of LAT and ELISA on serum samples:

\begin{tabular}{|c|c|c|c|c|}
\hline \multirow{2}{*}{$\begin{array}{c}\text { No. of serum } \\
\text { samples }\end{array}$} & \multicolumn{2}{|c|}{ ELISA } & \multicolumn{2}{c|}{ Latex Agglutination Test (LAT) } \\
\cline { 2 - 5 } & positive & Negative & Positive & Negative \\
\hline 80 & $54(67.5 \%)$ & $26(32.5 \%)$ & $54(67.5 \%)$ & $26(32.5 \%)$ \\
\hline
\end{tabular}

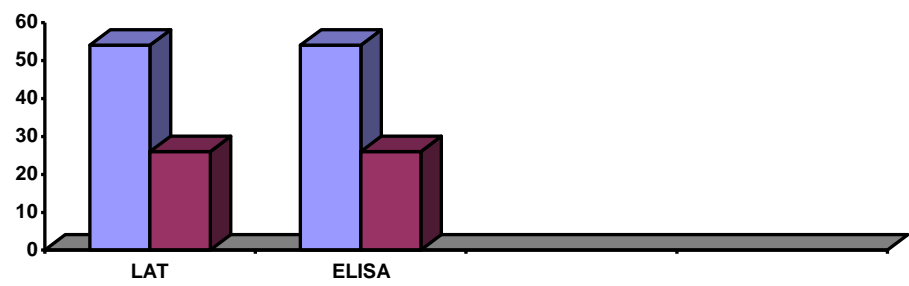

Chart 2: Results of LAT and ELISA on serum samples:

\section{DISCUSSION}

The need for epidemiological data on outbreaks of $M$. bovis is crucial to prevent the spread of the pathogen and to eradicate the sources. This need is accentuated for $M$. bovis since there is no vaccine available and the organism has been shown to be highly resistant to antibiotic therapy (Adegboye et al., 1995 and Byrne et al., 2000).

Diagnosis of mycoplasma infection in milk has developed primarily upon microbiological culture of udder secretions. Although the reliability of this method is reasonably satisfactory, it is time consuming. Inoculated plates must be incubated at least two to three days before colonies may be observed and should not be considered as negative before seven days of incubation. Determination of mycoplasma species has required further study which may biochemical or immunological. (Martenz et al., 1990). 
In this work, M. bovis isolation bear more over prevalence (30\%) from cases of clinical mastitis, these results determined the endemic status of the herd under experiment. These results agreed with Ghadersohi et al. (1999) that reported the isolation percentage $43 \%$ and $62 \%$ in herds positive for $M$. bovis in Victoria and North Queensland, respectively. M. Bovis was detected in $77 \%$ of cows of which $19 \%$ alone had $M$. bovis without any other bacteria, $17 \%$ had $M$. bovis in combination with major mastitis pathogens and $40 \%$ had $M$. bovis in combination with non-major mastitis pathogens. On the other hand, M. bovis was detected in $18 / 219(8.2 \%)$ quarter milk samples collected from cases of bovine clinical mastitis in Northern Greece between November 1997 and March 1999. The cases occurred in 2/37 (5.4\%) of the herds examined. The microorganism was isolated from bulk milk tank samples (BTS) from the two positive herds but was not isolated from 111 composite milk samples collected from clinically healthy cows from all 37 herds (Filioussis et al., 2007).

The bacteriological isolation of $M$. bovis is the gold test for diagnosis but discontinues shedding of mycoplasma; progressive acidification of milk may cause reduced viability of mycoplasma. Also, a high percentage of bacterial flora may hinder the growth of mycoplasma in selective agar plates and making the identification of mycoplasma colonies difficult (Tola et al., 1997). This explains why the results of IELISA and LAT were higher than the isolation and also this increase the need for the serological test. M. bovis antibodies were detected in $33(41.25 \%$ ) milk samples by indirect ELISA while by culture only $24(30 \%)$ milk samples were positive. These results indicated the potential value of the indirect ELISA for the detection of cows which have recently developed $M$ bovis mastitis during the early stages of an outbreak.

The results indicated that the sensitivity of positive cases by LAT $54(67.5 \%)$ was also equal to the results by ELISA. A test that allows rapid and inexpensive primary herd screening prior to confirmatory laboratory diagnosis (PCR or ELISA) should be useful in the field. In contrast to other diagnostic tests, no expensive equipments or reagent are required (e.g. ELISA plate reader, PCR machines, gel electrophoresis equipments, enzymes, etc.), and the results can be obtained in situ within few minutes. The requirements for LAT are minimal: glass slides (which are inexpensive) and disposable plastic droppers. The stability of the beads after storage for 6 months in refrigerator was not affected. 


\section{ACKNOWLEDGMENT}

The author present acknowledgment for Dr: Hassan, H.M. Head of immunology unit, Animal Reproduction Research Institute (ARRI) for valuable help.

\section{REFERENCES}

Adegboye, D.S.; Rasberry, U.; Halbur, P.G.; Andrews, J.J. and Rosenbusch, R.F. (1995): Monoclonal antibody-based immunohistochemical technique for the detection of $M$. bovis in formalin-fixed, paraffin embedded calf lung tissues. J. Vet. Diagn. Invest. 7, 261-265

Ayling, R.D.; Baker, S.E.; Peek, M.L.; Simon, A.J. and Nicholas, R.A.J. (2000): Comparison of in vitro activity of danofloxacin, florfenicol, oxytetracycline, spectinomycin and tilmicosin against recent field isolates of $M$. bovis. Vet. Rec. 146, 745-747.

Bernadette Hayman, Robert Hirst (2003): Development of a semi-nested PCR for the improved detection of $M$. bovis from bovine milk and mucosal samples Vet. Microbiol. 91 (2-3): 91-100.

Byrne, W.J.; Ball, H.J.; Brice, N.; McCormack, R.; Baker, S.E.; Ayling, R.D. and Nicholas, R.A.. (2000): Application of an indirect ELISA to milk samples to identify cows with $M$. bovis mastitis. Vet. Rec. 146 (13):368-9

Caswell, J.L. and Archambault, M. (2007): M. bovis pneumonia in cattle. Anim. Health Res. Rev. 8 (2):161-86.

Filioussis, G.; Christodoulopoulos, G.; Thatcher, A.; Petridou, V. and Bourtzi-Chatzopoulou, E. (2007): Isolation of M. bovis from bovine clinical mastitis cases in Northern Greece. Vet. J. 173(1): 215-218.

Ghadersohi, A.; Hirst, R.G.; Forbes-Faulkener, J. and Coelen, R.J. (1999): Preliminary studies on the prevalence of $M$. bovis mastitis in dairy cattle in Australia Vet. Microbiol. 65 (3): 185194.

González, R.N. and Wilson, D.J. (2003): Mycoplasmal mastitis in dairy herds. Vet Clin. North Am Food Anim Pract. 19 (1):199-221

Hajkova, M. and Jurmanova, K. (1986): Detecting mycoplasma antibodies by enzyme linked immunosorbant assay. Vet. Med. 31(8): 487-496. 
Kende, M. (1969): Antibody response of animals to Mycoplasma pneumoniae measured by latex agglutination. Applied Microbiol. 17 (2): 275-279.

Kinde, H.; Daft, B.M.; Walker, R.L.; Charlton, B.R. and Petty, R. (1993): M. bovis associated with decubital abscesses in Holstein calves. J. Vet. Diagn. Invest. 5: 194-197.

Krogsgaard, A.J. (1971): Indirect hemagglutination with mycoplasma antigens: Effect of $\mathrm{pH}$ on antigen sensitization of tanned fresh and formalinized sheep erthrocytes. Appl.Microbiol. 22 (5): 756759.

Martinez, F.I.; Jasper, D.E.; Stott, J.L.; Cullor, J.S. and Dellinger, J.D. (1990): Immunobinding assay for detection of M. bovis in milk. Canad. J. Vet. Res. 542: 251-255.

Nicholas, R.A.J. and Ayling, R.D. (2003): M. bovis disease, diagnosis, and control. Res. Vet. Sci. 74 (2): 105-112.

Pfutzner, H. and Sachse, K. (1996): M. bovis as an agent of mastitis, pneumonia, arthritis and genital disorders in cattle. Rev. Sci. Tech. 15:1477-1494.

Rodwell, A.W. and Whitcomb, R.F. (1983): Methods for direct and indirect measurement of mycoplasma growth. In Methods in Mycoplasmology Vol. I Mycoplasma characterization edited by Razin, S. and Tully, J.G. Academic Press.

Ruhnke, H.L. and Rosendal, S. (1989): Useful protocols for diagnosis of animal mycoplasmas. WAVLD Mycoplasma Workshop Vet. Microbiol. and Immunol. Dept. Ontario Vet. Collage, Guelph, Ontario, Canada NIC2W1.

Satyanarayan, A.N.; Paulsson, M. and Wadstrom, T. (1988): Particle agglutination assays for rapid detection of fibronectin, fibrinogen, and collagen receptors on Staphylococcus aureus. J. Clinical Microbiol. 26(2):1549-1554

Tola, S.; Angioi, A.; Rocchigiani, A.M.; Idini, G.; Manunta, D.; Galleri, G. and Leori, G. (1997): Detection of Mycoplasma agalactiae in sheep milk samples by polymerase chain reaction. Vet. Microbiol. 54: 17-22.

Wilson, D.J.; Skirpstunas, R.T.; Trujillo, J.D.; Cavender, K.B.; Bagley, C.V. and Harding, R.L. (2007): Unusual history and initial clinical signs of $M$. bovis mastitis and arthritis in first-lactation cows in a closed commercial dairy herd. J. Am. Vet. Med. Assoc. 230 (10):1519-1523. 